\title{
Der arme Heinrich vou
}

\section{Hartmann von Aue}

\author{
Herausgegeben \\ von \\ Hermann Paul
}

Siebente auflage

besorgt von Albert Leitzmann

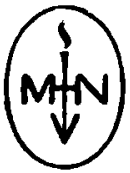

Max Niemeyer Verlag

Halle (Saale) 


\section{Alle rechte, \\ auch das der iubersetzung in fremde sprachen, vorbehalten Copyright by Max Niemeyer Verlag, Halle (Saale), 1930 \\ Printed in Germany}

Altdentsche textbibliothek, begründet von $\mathrm{H}$. Panl herausgegeben vou $\rightarrow$. Baesecke nr. 3 